\title{
DIVERSITY AND ABUNDANCE OF SMALL MAMMALS IN THE SERENGETI KOPJES, TANZANIA
}

\author{
CD Timbuka and $\mathbf{J}$ Kabigumila \\ Department of Zoology and Marine Biology, University of Dar es Salaam, \\ P.O. Box 35064 Dar es Salaam, TANZANIA
}

\begin{abstract}
Diversity and abundance of small mammals in the Serengeti kopjes were studied between November 2000 and February 2002. From 22,500 trap-nights and 3,300 bucket-nights, 4,903 small mammals in 18 species, 14 genera, 6 families and 3 orders were recorded. Muridae was the most dominant family with nine species. The highest number of species was recorded in the Maasai (14), Mbuzi Mawe (13) and Seronera (12) kopjes. The least number of species recorded in the Simba, Barafu and Wogakuria kopjes, with eight species each. Species diversity was highest in the Maasai kopjes $\left(H^{\prime}=2.337\right)$ and lowest in the Wogakuria kopjes $\left(H^{\prime}=1.794\right)$, with fourteen and eight species, respectively. No significant difference in species diversity was detected between woodland and grassland kopjes, or between seasons. Distribution of species did not vary significantly between the kopjes, with most species being widespread. These include Tatera boehmi, Arvicanthis lacernatus, Graphiurus murinus and Crocidura sp. Catch rate varied from 0.519 in the Seronera kopjes to 0.103 in the Barafu kopjes. However, the difference in catch rate between the kopjes was not significant. Catch rate was significantly higher during the dry season, particularly in the grassland kopjes. The most abundant species included Mastomys anatalensis, Acomys wilsoni, G. murinus and Crocidura sp.
\end{abstract}

\section{INTRODUCTION}

Among the features that increase the scenic beauty of the Serengeti National Park are the spectacular granite rocky outcrops known as kopjes. They were formed by orogenic events during the Late Precambrian, some 475-650 mya (Hay 1976). Most of the kopjes have rounded shapes due to weathering, and protrude like "islands" from the surrounding plains to an elevation of up to $30 \mathrm{~m}$ (Anderson and Talbot 1965, Hay 1976). The kopjes are unique habitats in that their vegetation is rich species composition and varies strikingly from the adjacent vegetation on the plains. This variation is probably due to several factors including heterogeneous topography, concentration of organic and inorganic matter in the fissures and around the kopjes and exposure to fire (Hoeck 1975).

Due to their uniqueness, the kopjes also support unique and diverse fauna (Sinclair and Arcese 1995) and contribute considerable ecological diversity to the ecosystem in terms of habitats and provision of shelter to a variety of fauna (Houston 1968, Hoeck 1975). Various invertebrates, amphibians, reptiles, birds and small mammals reside in the kopjes. Some animals take refuge in the kopjes to feed during drought, while others especially the predators may use the kopjes as vantage points when hunting. The kopjes also store water, which is important to flora and fauna. It is thus believed that without such habitats, lions and other large animals might be unable to survive the dry season on the plains (TANAPA 1997).

Although the Serengeti National Park is well known, studies involving smaller mammals are relatively scanty and less detailed. Missone and Verschuren (1966) recorded 25 rodent species from the park and described the broad ecological biotopes in which different species were captured. Hendrichs (1970) recorded 36 species of 
rodents, which represented the largest number of species recorded from the park. Root (undated) produced a documentary film "islands in a sea of grass" on the animal life of the Serengeti kopjes, showing that these habitats were like "oceanic islands" supporting a variety of species amidst a "sea of grass". He showed that the kopjes were rich in mammals such as free-tailed bats, rodents, hyraxes, mongoose, caracal, and klipspringer. He concluded that the kopjes, like oceanic islands, support many species, which do not live in the surrounding areas of grass. Although not well studied, small mammals are important contributors to biodiversity of savannah ecosystems in subSaharan Africa (Linzey and Kesner, 1997). Apart from being food for predators, they are also important consumers. Because of their food and cover requirements, they are likely to be adversely affected by habitat disturbance.

The need to study the small mammals of the Serengeti kopjes was due to various factors. Firstly, the kopjes are among the vulnerable and rare habitats in the park; they are fragile, yet their fauna is not well understood. Secondly, human activities have been on the increase in the park but the impact of such activities on the kopjes and their fauna is unknown. The study reported here examined the diversity, distribution, and abundance of small mammals in the kopjes with a view to providing baseline data for conserving these unique habitats.

\section{MATERIALS AND METHODS \\ Study area}

The Serengeti National Park covering an area of some $12,763 \mathrm{~km}^{2}$, is situated between $1^{\circ} 28^{\prime}-3^{\circ} 17^{\prime} \mathrm{S}$ and $33^{\circ} 50^{\prime}-35^{\circ} 20^{\prime} \mathrm{E}$ (Herlocker 1976) (Fig. 1). It occupies a vast upland area varying in elevation from 1,162 $\mathrm{m}$ at Lake Victoria to $1,860 \mathrm{~m}$ in the northeast. The climate is typically semiarid, with bimodal rainfall, with the "short rains" in November-December and the "long rains" in March through May. There is a rainfall gradient from 514-688 mm year $^{-1}$ in the southeastern plains through $857-976 \mathrm{~mm}$ in the central woodlands and western corridor, to $972-1,100 \mathrm{~mm}_{\text {year }}{ }^{-1}$ in the north (Norton-Griffiths et al. 1975).

Herlocker (1976) gives a detailed description of the Serengeti National Park and its vegetation. The basic zonation of vegetation throughout the park is strongly influenced by the patterns of rainfall and climate, in particular the severity of the dry season (Norton-Griffiths et al. 1975). Grassland covers most of the park, being extensive in the dry southeast on the Serengeti plains and parts of the north and west of the park. Alkaline-tolerant grasses and forbs (Herlocker 1976) dominate the north and west of the park. Woodland extends from Seronera, to south and east of the park. Acacia species are the most dominant, except for small patches of Terminalia and Combretum in the dry subhumid north around Kogatende (Herlocker 1976). West of the park, the Acacia woodland has a herbaceous layer reaching from 0.5 to $1.5 \mathrm{~m}$ in height dominated by Themeda triandra and Eustachys paspaloides on well drained soils and by Pennisetum mezianum on poorly drained soils (Herlocker 1976). 


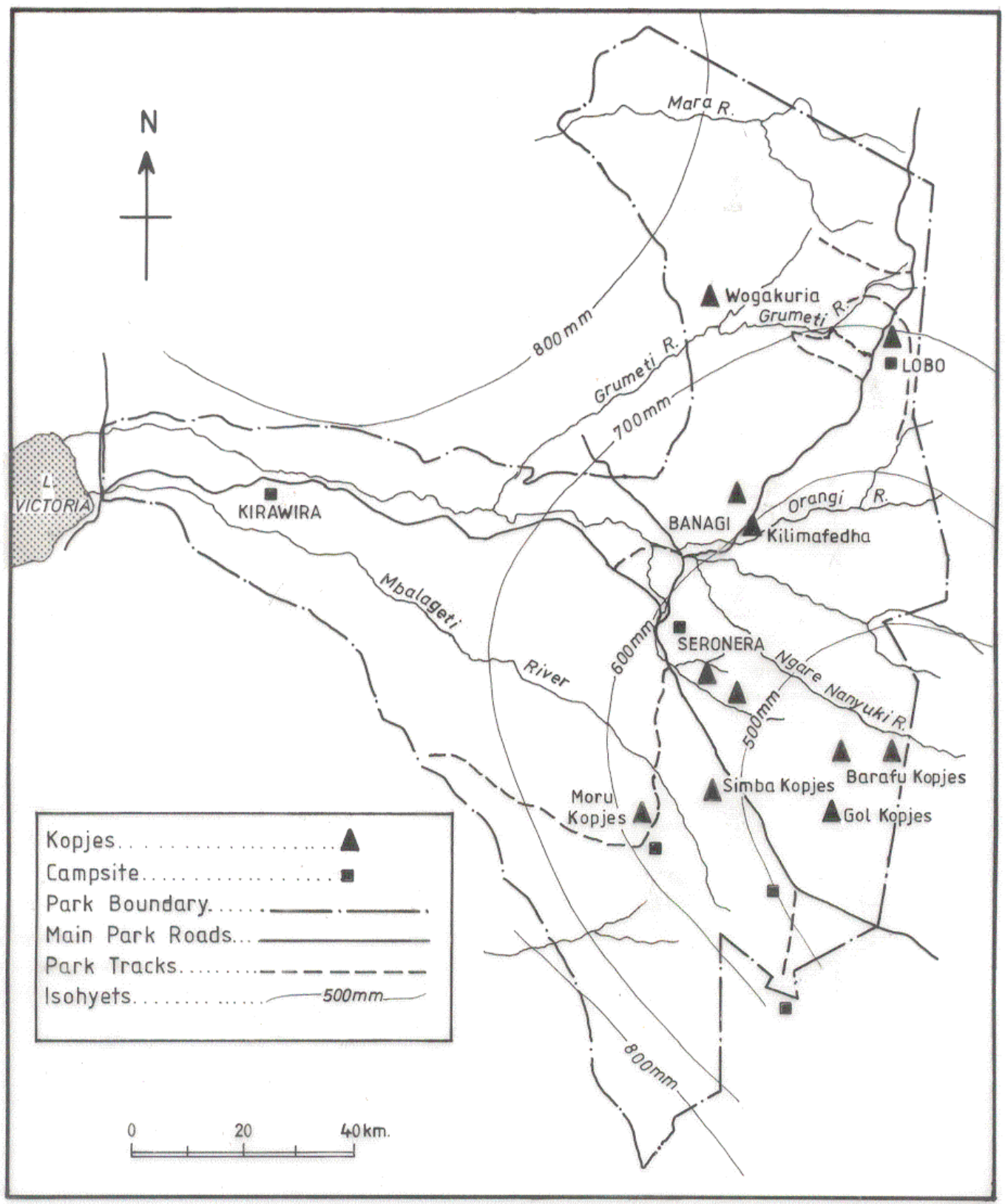

Figure 1: Map of study area showing location of the kopjes and rainfall isohyets.

\section{Methods}

Prior to the study, a reconnaissance survey was conducted to locate suitable kopjes. Major considerations were kopjes lying along a climatic gradient from the dry southeast grass plains to the wetter northern woodlands and the size of the kopjes. Ten kopjes located on the grass plains (i.e. Simba, Moru, Gol, Barafu and Maasai) and in the woodlands (i.e. Seronera, Togoro, 
Mbuzi Mawe, Lobo and Wogakuria) (Fig. 1) were selected for setting traps.

In this study, small mammals included shrews, elephant shrews and rodents. These were captured using pitfall buckets and Sherman live traps. Plastic pails measuring $30 \times 30 \mathrm{~cm}$ in diameter and depth were buried in the ground with the opening flush with the surface. A polythene drift fence was constructed to intercept and redirect animals moving on the ground into pitfall traps at various sites (Corn and Bury 1990). Each pitfall line contained eleven buckets at $5 \mathrm{~m}$ interval. The buckets had small drainage holes at the bottom. The Sherman traps were baited after each check with a mixture of peanut butter, sardines, rice and maize flour. A combination of baits was used because different species get attracted to different types of baits (Bond et al. 1980, Leirs et al. 1995, Steele et al. 1984; Stanley, et al. 1996, Willan 1979).

A total of 110 pitfall buckets and 150 Sherman traps were used at a time at each site. Traps and pitfall lines were checked twice a day, early in the morning immediately following sunrise and in the late afternoon. The animals were marked on first capture for future identification by clipping toes in a coded pattern, in order to obtain abundance estimates and avoid multiple recording. The animals were identified using the procedures of Delany (1971), Meester and Setzer (1971), Kingdon (1974), and DeBlase and Martin (1974), then counted and released immediately. Where possible, a set of two males and females for each species were preserved as voucher specimens. Specimens were either prepared as study skins or preserved in $70 \%$ alcohol. Animals, which could not be identified in the field, were labelled, fixed, preserved and taken back to the University of Dar es Salaam for identification and preservation.

\section{Data analysis}

The data were analysed to show diversity, distribution and abundance of the various species. The distribution of species in the various kopjes was recorded as present or absent and analysed using the Cochran's Q test (Zar, 1996). The Shannon-Wiener Index of Diversity, H' was used to calculate the diversity of species in the various kopjes. Seasonal variation in species diversity was tested using Hutchenson's (1970) adaptation of the t-test. Abundance of species in the various kopjes was assessed as the numbers of catches of the respective species per 100 trap- or bucket nights, i.e. the proportion of catches relative to the number of traps set over a given period. Variations in catch rate of species among the kopjes and seasons were analysed using the Kruskal-Wallis test, $\mathrm{H}$ (Zar, 1996) and followed by Dunn's multiple comparisons test if $\mathrm{H}$ was significant.

\section{RESULTS}

\section{Species diversity}

From 22,500 trap- and 3,300 bucket nights, 4,903 small mammals were captured, including eighteen species in three orders, six families and fourteen genera (Table 1). All the animals were first-time captures. The families recorded were Soricidae (3), Gerbillidae (2), Muridae (9), Cricetidae (2), Myoxidae (1), and Macroscelididae (1). Simba, Barafu and Wogakuria kopjes had the least number of species with eight species each while Maasai had the highest number of species (14) closely followed by Mbuzi Mawe (13) and Seronera (12). Moru and Togoro had ten species each while Lobo and Gol had nine species each.

The highest species diversity was recorded in the Maasai kopjes $\left(\mathrm{H}^{\prime}=2.337\right)$, and the lowest in the Wogakuria kopjes $\left(\mathrm{H}^{\prime}=1.794\right)$ (Table 1). Generally, species diversity was higher in the grassland $\left(\mathrm{H}^{\prime}=1.051\right)$ than woodland kopjes $\left(\mathrm{H}^{\prime}=0.910\right)$, but the difference was not significant $(\mathrm{t}=0.014$, $\mathrm{DF}=20, \mathrm{P}>0.500)$. No significant variation 
in species diversity was detected between the wet and dry season, and transition period
(Kruskal-Wallis test, $\mathrm{H}=1.953 ; \mathrm{DF}=2 ; \mathrm{P}$ $=0.376)$ (Fig. 2).

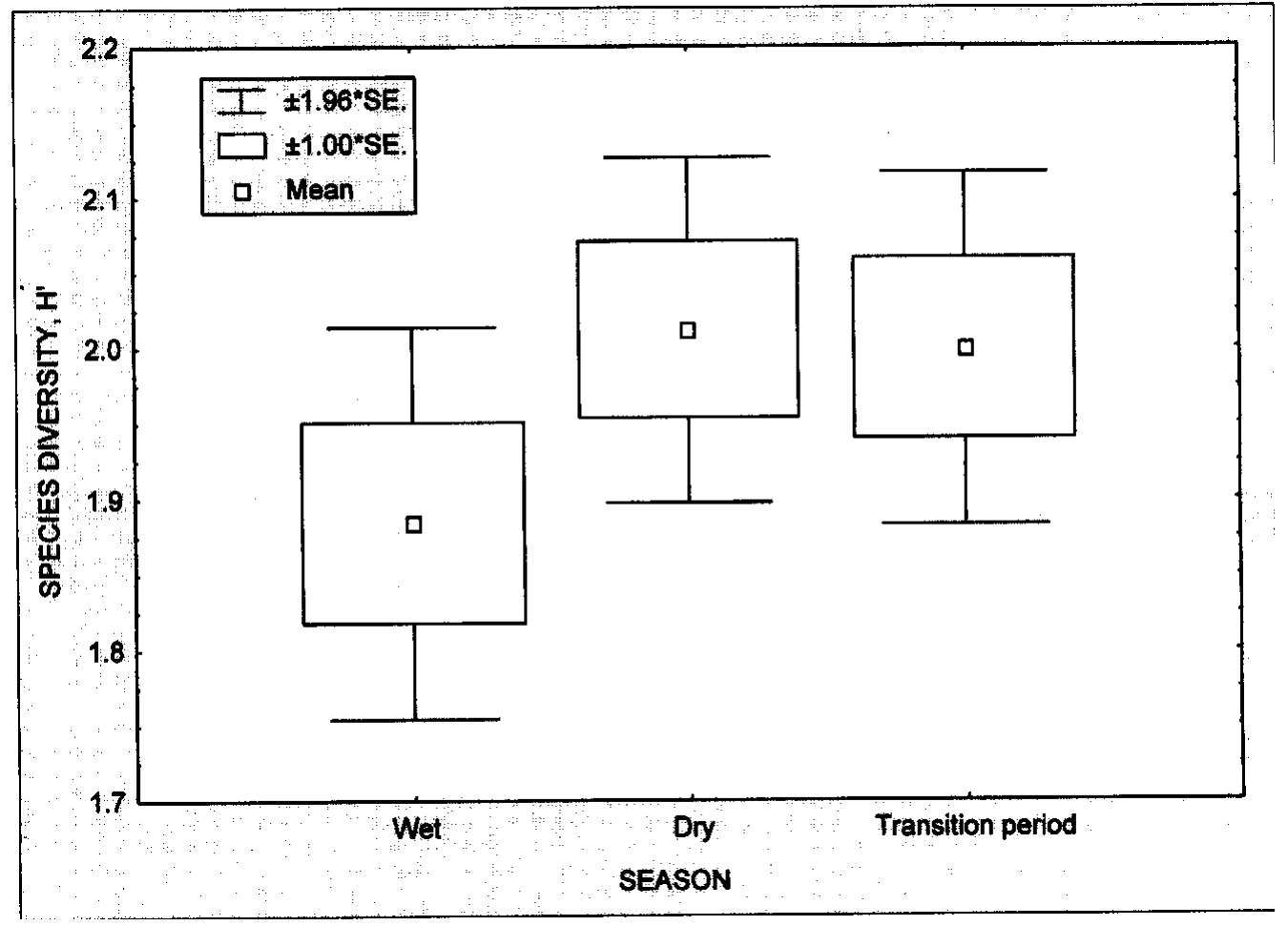

Figure 2: Seasonal variation in species diversity of small mammals in the Serengeti kopjes.

\section{Distribution of species}

The distribution of species did not vary significantly among the kopjes (Cochran's Q test, $\mathrm{Q}=9.925 ; \mathrm{DF}=9 ; \mathrm{P}=0.140)$. Except for one shrew and some muroid rodents, most species were widespread in the kopjes (Table 1). Tatera boehmi, Arvicanthis lacernatus, Graphiurus murinus and Crocidura sp. were the most widespread with occurrence in $80 \%$ of the kopjes. Aethomys sp. and Elephantulus rufescens were the least widespread, with occurrence in only $30 \%$ of the kopjes.

\section{Catch rate}

The Seronera kopjes had the highest catch rate $(0.519)$ followed by the Maasai kopjes (0.447), while the Barafu kopjes had the least catch rate (0.103) (Table 1). Mastomys natalensis was the most abundant accounting for $14.95 \%$ of the total captures. Other abundant species included Acomys wilsoni, Graphiurus murinus and Crocidura sp. Elephantulus rufescens was the least common species, accounting for only $0.35 \%$ of the total captures.

No significant difference in catch rate was detected when the kopjes were compared (Kruskal-Wallis test, $\mathrm{H}=15.603, \mathrm{DF}=17$, $\mathrm{P}=$ 0.076). However, there was a significant seasonal variation in catch rate among the kopjes (Kruskal-Wallis test, $\mathrm{H}=$ 10.445; $\mathrm{DF}=2 ; \mathrm{P}=0.005$ ) (Fig. 3 ). The wet and dry season showed a significant difference (Dunn's test: $\mathrm{P}<0.001$ ), but not the dry season and transition period. Generally, catch rate was higher during the 
dry season (Fig. 3) particularly in the grassland kopjes (Table 1). Catch rate remained uniform throughout the study period in the woodland kopjes (Table 1).

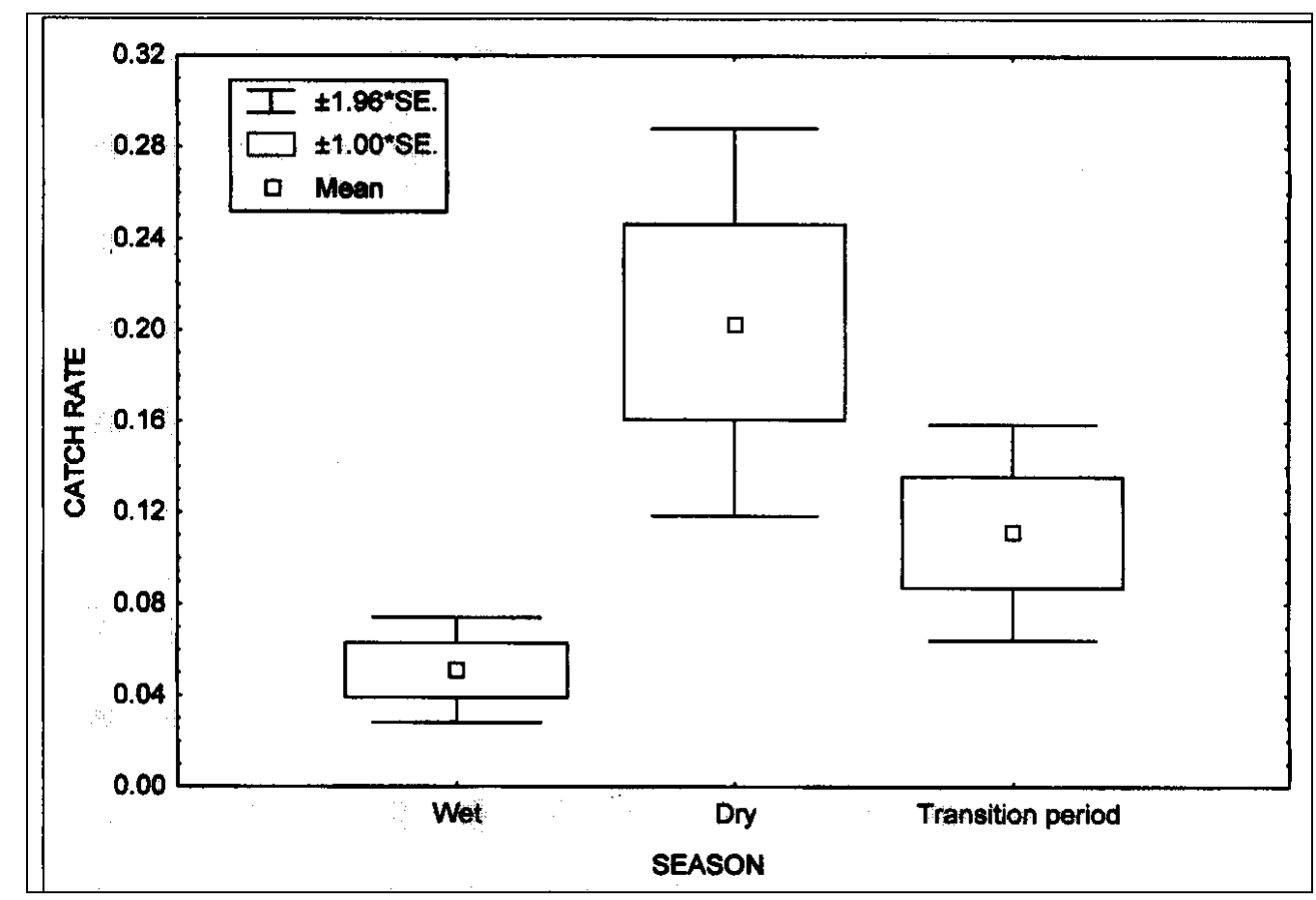

Figure 3: Seasonal variation in catch rate of small mammals in the Serengeti kopjes. 
Table 1: $\quad$ Diversity, abundance and distribution of species of small mammals in the Serengeti kopjes $(-=$ absence $)$.

\begin{tabular}{|c|c|c|c|c|c|c|c|c|c|c|c|}
\hline \multirow[b]{3}{*}{ Species } & \multicolumn{10}{|c|}{ Kopjes } & \multirow[t]{3}{*}{$\begin{array}{l}\text { Total catch } \\
\text { rate }\end{array}$} \\
\hline & \multicolumn{5}{|c|}{ Grassland } & \multicolumn{5}{|c|}{ Woodland } & \\
\hline & Moru & Simba & Gol & Barafu & Maasai & Seronera & Togoro & $\begin{array}{l}\text { Mbuzi } \\
\text { Mawe }\end{array}$ & Lobo & Wogakuria & \\
\hline \multicolumn{12}{|l|}{$\begin{array}{l}\text { INSECTIVORA } \\
\text { Soricidae (Shrews) }\end{array}$} \\
\hline Crocidura bicolor & 0.021 & 0.015 & 0.012 & 0.021 & 0.043 & 0.056 & - & 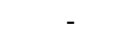 & - & 0.040 & 0.208 \\
\hline Crocidura flavescens & - & - & - & - & 0.006 & 0.004 & 0.005 & 0.003 & - & - & 0.018 \\
\hline $\begin{array}{l}\text { Crocidura sp. } \\
\text { RODENTIA }\end{array}$ & 0.010 & 0.023 & 0.016 & - & 0.073 & 0.061 & - & 0.043 & 0.032 & 0.034 & 0.292 \\
\hline \multicolumn{12}{|l|}{ Gerbillidae (Gerbils) } \\
\hline Tatera robusta & 0.021 & 0.015 & 0.036 & - & 0.028 & 0.019 & - & 0.022 & - & - & 0.141 \\
\hline Tatera boehmi & 0.017 & - & 0.029 & 0.021 & 0.032 & 0.017 & - & 0.009 & 0.007 & 0.008 & 0.142 \\
\hline \multicolumn{12}{|c|}{ Muridae (Mice and Rats) } \\
\hline Arvicanthis lacernatus & 0.010 & - & 0.024 & 0.015 & 0.020 & 0.008 & 0.012 & 0.015 & 0.006 & - & 0.108 \\
\hline Acomys dimidiatus & - & 0.019 & - & 0.013 & 0.049 & 0.048 & 0.026 & - & 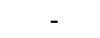 & 0.015 & 0.169 \\
\hline Acomys wilsoni & - & 0.017 & 0.028 & 0.017 & 0.071 & 0.064 & - & 0.043 & 0.037 & - & 0.278 \\
\hline Aethomys kaiseri & - & - & - & - & - & - & 0.009 & 0.015 & - & 0.012 & 0.036 \\
\hline Grammomys dolichurus & - & - & - & 0.003 & - & - & 0.003 & 0.006 & 0.004 & - & 0.015 \\
\hline Lemniscomys barbarus & - & 0.003 & 0.004 & - & 0.004 & - & 0.006 & 0.003 & - & - & 0.020 \\
\hline Mastomys natalensis & 0.028 & - & - & - & 0.043 & 0.130 & 0.037 & 0.046 & 0.041 & - & 0.326 \\
\hline Mus minutoides & 0.004 & - & 0.008 & - & 0.012 & - & - & - & 0.008 & - & 0.032 \\
\hline Rattus rattus & 0.018 & 0.018 & - & - & 0.006 & 0.028 & - & - & 0.017 & - & 0.087 \\
\hline \multicolumn{12}{|c|}{ Cricetidae (Cricetid Rats) } \\
\hline Dendromus melanotis & 0.003 & 0.004 & - & - & - & 0.004 & 0.005 & - & - & 0.003 & 0.018 \\
\hline $\begin{array}{l}\text { Steatomys pratensis } \\
\text { Myoxidae (Dormice) }\end{array}$ & - & - & 0.008 & - & - & - & 0.004 & 0.004 & - & 0.005 & 0.020 \\
\hline $\begin{array}{l}\text { Graphiurus murinus } \\
\text { MACROSCELIDEA }\end{array}$ & 0.021 & - & - & 0.011 & 0.056 & 0.081 & 0.034 & 0.031 & 0.015 & 0.013 & 0.261 \\
\hline \multicolumn{12}{|c|}{ Macroscelididae (Elephant Shrews) } \\
\hline Elephantulus rufescens & - & - & - & 0.002 & 0.004 & - & - & 0.001 & - & - & 0.008 \\
\hline Total catch rate & 0.155 & 0.113 & 0.164 & 0.103 & 0.447 & 0.519 & 0.140 & 0.242 & 0.167 & 0.129 & 2.179 \\
\hline No. of species & 10 & 8 & 9 & 8 & 14 & 12 & 10 & 13 & 9 & 8 & - \\
\hline Species diversity, H' & 2.154 & 1.932 & 2.010 & 1.911 & 2.337 & 2.130 & 1.935 & 2.180 & 1.935 & 1.794 & - \\
\hline
\end{tabular}




\section{DISCUSSION \\ Species diversity}

Compared to other areas such as Dakawa Brachystegia woodlands (Leirs 1995) and the Eastern Arc Mountains (Makundi 1993, Stanley et al. 1998, Njau 1999), the Serengeti kopjes are among the richest areas in species composition. Leirs (1995) recorded thirteen genera of small mammals in the Dakawa woodlands, while Makundi (1993) recorded seven species in five genera in the Western Usambara Mountains. Njau (1999) recorded twelve species in the Udzungwa Mountains while Stanley et al. (1998) recorded fourteen genera in the Eastern Arc Mountains. These areas are known to contain some of the most biologically diverse and endemic-rich montane ecosystems in all of Africa. Comparison with similar studies elsewhere is constrained by the paucity of data.

The Maasai, Mbuzi Mawe and Seronera kopjes had higher species diversity than most others, presumably due to their varied microhabitats provided by the thick undergrowth. Undergrowth is particularly crucial at the peak of the dry season and transition period, when the areas adjacent to the kopjes are dry. However, it is possible that some animals were missed at the Barafu, Moru and Gol kopjes, as they were difficult of access during the wet season. The Wogakuria kopjes in the woodlands did not differ in habitat suitability from the adjacent vegetation, hence attracting fewer species.

The large number of species recorded in the Serengeti kopjes represents several major life forms such as terrestrial (e.g. $M$. natalensis), arboreal (e.g. D. melanotis) and fossorial (e.g. Tatera sp.). It also represents small mammals of all the major feeding habits such as insectivores (e.g. Crocidura sp., E. rufescens), omnivores (e.g. M. natalensis) and herbivores (e.g. Lemniscomys barbarus, Acomys sp.). These results suggest that the study methods, traps and baits chosen were suitable for sampling the species in the kopjes. Although some species might have avoided the standard traps, the present study agrees with Maddock (1992) and Stephenson (1994) in showing that a combination of trapping techniques is needed to determine species composition, distribution and abundance.

No significant difference in species diversity was found among the woodland and grassland kopjes, although the latter were more heterogeneous in habitat composition than the adjacent plains, and thus likely to attract more species. This is probably due to the availability of food, shelter and cover, in both types of kopjes. In addition, the Serengeti kopjes have little variation in altitude and therefore may support species with similar altitudinal requirements. Other workers (e.g., Bond et al. 1980; Bowland and Perrin 1988, RoweRowe and Lowry 1982), have shown that the diversity of small mammals can be influenced by factors such as cover, grazing patterns and vegetation structure and thickness.

\section{Distribution of species}

There was no significant difference in species distribution among the Serengeti kopjes. With a few exceptions, most of the species were widespread. However, $M$. natalensis appeared to be the most dominant species, coexisting with other species in the kopjes. Vesey-Fitzgerald (1966) found Mastomys on the Congo River Floodplain to be associated with Arvicanthis in the grassland, and Aethomys and Acomys in the rocky outcrops. The species also shared warrens with Tatera. In the present study, the species occurred with Rattus, both species being partial to human dwellings (Vesey-Fitzgerald 1966, Kingdon 1971). Mastomys tended to be associated with Arvicanthis in all the kopjes it was recorded, although the latter was more widespread. Mastomys has generally been regarded as the most adaptable and the most widespread rodent in East Africa (Hubbard 1972), and the genus is believed 
to be the most abundant in sub-Saharan Africa (Leirs 1995). Although M. natalensis was the most abundant species, it was the least distributed of the four species recorded in the kopjes, suggesting some form of habitat choice. Leirs (1995) has also reported differential habitat use in Mastomys suggesting that the species preferred some sites with rich cover. Elephantulus rufescens and $A$. kaiseri were the least distributed small mammals suggesting that some species are not randomly distributed or dispersed among habitats but rather restricted to areas of preference. However, variation in catch rate among the kopjes suggests that some species were not equally dominant in the various kopjes.

Variation in species distribution within the Serengeti kopjes might also be ascribed to differences in plant species composition and diversity among the kopjes. Hayward and Phillipson (1979) have shown relationships between habitats and species distribution and diversity. In the tropics, the characteristic diversified plant community has been held among the factors responsible for the large numbers of small mammal species, each depending in one way or another, on a particular group of plant species for both food and other requirements. Animal species vary in their dependence on habitats; certain species can live only within a very specific habitat (specialists), while others utilise a wide spectrum of habitats (generalists). Happold and Happold (1990) have shown that grasslands with the densest cover support a greater number of individual rodents than the exposed ones.

\section{Catch rate}

Mastomys natalensis was the most abundant species as indicated by the multiple captures. Multiple captures have been used as an index of high density (Leirs 1995). Mastomys natalensis also dominated in most of the areas where it was captured except for two sites dominated by Acomys. The multiple captures of $M$. natalensis in the kopjes may be explained by its social habits with several families sharing a burrow (Kingdon 1971). Mastomys is regarded as the most adaptable and most widespread rat in East Africa (Hubbard 1972), and indeed throughout sub-Saharan Africa (Leirs 1995, Granjon et al. 1997). In Malawi, $M$. natalensis accounted for almost $50 \%$ of all prey in the pellets of the Grass Owl (Tyto capensis) (Hubbard 1972).

Other abundant species included Crocidura sp. and A. wilsoni, which are known to be numerous and can tolerate varied habitats. Acomys, for example, is found over most of the drier areas, but depends on natural shelters beneath the rocks, other rodent warrens, termitaria or houses (Kingdon 1974). It can even tolerate habitats exposed to severe pressure from human disturbance (Njau 1999). The species is also opportunistic, feeding on seeds, leaves, dry matter, invertebrates and organic debris. All the items were available in the kopjes. Similarly, Crocidura inhabits all vegetation types at all altitudes, mainly terrestrial, but is able to climb or swim. Their food comprises a wide range of invertebrates and small vertebrates. This might account for their successful habitation of the kopjes. Njau (1999) also recorded Crocidura among the most abundant small mammal species in the Udzungwa Mountains.

Grammomys dolichurus and E. rufescens were the least abundant with sightings mostly in undisturbed kopjes (e.g. Gol, Lobo, and Barafu). Njau (1999) made similar observations in the Udzungwa Mountains where Grammomys was restricted to undisturbed forest habitat types.

Catch rate was higher in the dry than wet season, suggesting that there were more individuals using the kopjes during this period, particularly those in the grassland. During the dry season, most species tended to confine themselves to the few available suitable sites in the kopjes. This could also explain why there was little variation in 
catch rate in the woodland kopjes, which had suitable adjacent sites virtually throughout the year. Elsewhere in East Africa, catch rates for small mammals were generally higher during the wet season. Oguge (1995) examined the seasonal abundance of $M$. natalensis and other small rodents in a sub-humid grassland community showing a positive correlation between abundance and precipitation. The increase in abundance was attributed to either immigration or reproduction, both of which add new individuals to the community. Our catch rates were lower during the wet season presumably due to the availability of suitable sites outside the kopjes.

Rodents are known to migrate from temporarily unfavourable sites to nearby refugia and to return when conditions are favourable (Christian 1977, Willan and Bigalke 1982). This might explain the high catch rate in the kopjes during the dry season when the adjacent areas were less favourable. Small mammals tend to move short distances (Bowland and Perrin 1993), with ranging distances being influenced by food scarcity. Oguge (1995) reported movements in $M$. natalensis at a range of $238 \mathrm{~m}$ in search of food when it was limited in distribution. It is possible that the seasonal changes in abundance observed in the present study were due to either migration and/or reproduction.

\section{ACKNOWLEDGEMENTS}

We would like to acknowledge the Associated Colleges of the Midwest-Dar es Salaam Link, the Tanzania Wildlife Research Institute and the University of Dar es Salaam for financing the study. The Tanzania National Parks kindly provided accommodation and permission for the study to be undertaken in Serengeti National Park.

\section{REFERENCES}

Anderson GD and Talbot LM 1965 Soil factors affecting the distribution of the grassland types and their utilisation by wild animals on the Serengeti plains, Tanganyika. J. Ecol. 53: 33-56.

Bond W, Ferguson M and Forsyth G 1980 Small mammals and habitat structure along altitudinal gradients in the Southern Cape Mountains. S. Afr. J. Zool. 15: 34-43.

Bowland AE and Perrin MR 1988 The effects of fire on the small mammal community in Hluhluwe Game Reserve. Z. Saugetierk. 53: 233-244.

Bowland AE and Perrin MR 1993 Wetlands as reservoirs of small mammal populations in Natal Drakensberg. $S$. Afr. J. Wildl. Res. 23: 39-43.

Christian DP 1977 Effects of fire on small mammal populations in a desert grassland. J. Mammal. 58: 423-427.

Corn PS and Bury RB 1990 Evaluation of pitfall trapping in northwestern forest: Trap arrays with drift fences. J. Wildl. Mgmt. 51: 112-119.

DeBlase AF and Martin RE 1974 A Manual of Mammalogy with Keys to the Families of the World. Wm. C. Brown Co. Publ. Dubuque.

Delany MJ 1971 The biology of small mammals in Malanja Forest, Uganda. J. Zool., Lond. 165: 85-129.

Granjon L, Duplantier J, Catalan J and Britton-Davidian J 1997 Systematics of the genus Mastomys (Thomas 1915) (Rodentia: Muridae): A Review. Belg. J. Zool. 127: 7-18.

Happold DCD and Happold M 1990 An ecological study of small rodents in the woodland savannah of Liwonde National Park, Malawi. J. Zool. Lond. 221: 219-235.

Hay RL 1976 Geology of the Olduvai Gorge. University of California Press, Berkley.

Hayward GF and Phillipson T 1979 Community structure and functional role of small mammals in the ecosystems. In: Stoddart D M (ed) 
Ecology of Small Mammals Chapman and Hall, London.

Hendrichs VH 1970 Schätzungen der Huftierbiomasse in der Dornbuschsavanne nördlich und westlich der Serengetisteppe in Ostrafrica nach einem neuen Verfahren und Bemerkungen Zur biomasse der anderen pflanzenfressenden Tierarten. Säugertierk. Mitt. 18: 237-255.

Herlocker D 1976 Woody Vegetation of the Serengeti National Park. College Station, Texas A and M University, Texas.

Hoeck HN 1975 Differential feeding behaviour of sympatric hyrax Procavia johnstoni and Heterohyrax brucei. Oecologia 22: 15-47.

Houston DC 1968 A short survey of vertebrate animals living on the rock outcrops of the Serengeti National Park, Tanzania. Mimeo. Serengeti Research Institute, Arusha.

Hubbard CA 1972 Observations on the life histories and behaviour of some small rodents from Tanzania. Zool. Afr. 7: 419-449.

Hutchenson K 1970 A test for comparing diversities based on the Shannon formula. J. Theor. Biol. 29: 151-154.

Kingdon J 1971 East African Mammals. Vol. IIA. Academic Press, London.

Kingdon J 1974 East African Mammals. Vol. IIB. Academic Press, London.

Leirs H 1995 Population ecology of Mastomys natalensis (Smith 1834) (Multimammate rats): Implications for rodent control in Africa. Agric. Edn. No. 35. Belgian Administration for Development Cooperation, Brussels.

Leirs HR, Verhagen R, Verhyen $\mathrm{W}$ and Perrin MR 1995 The biology of Elephantulus brachyrhynchus in natural miombo woodland in Tanzania. Mammal. Rev. 25: 45-49.

Linzey AV and Kesner MH 1997 Small mammals of a woodland-savannah ecosystem in Zimbabwe. I. Density and habitat occupancy patterns. J. Zool. Lond. 243: 137-152.
Maddock AH 1992 Comparison of two methods for trapping rodents and shrews. Isr. J. Zool. 38: 333-340.

Makundi RH 1993 Annual changes of reproduction in rodents in the western Usambara Mountains, northeast Tanzania. Proc. Rod. Res. Proj. Sokoine University of Agriculture, Morogoro, pp 45-62.

Meester J and Setzer AW 1971 The Mammals of Africa: An Identification Manual. Smithsonian Institution Press, Washington.

Missone X and Verschuren J 1966 Les rongeurs et lagomorphoes de la region $\mathrm{du}$ Parc National du Serengeti. Mammalia 30: 517-537.

Njau DR 1999 The abundance and habitat preference of small mammals in Udzungwa ecosystem, Tanzania. M.Sc. Thesis, University of Dar es Salaam.

Norton-Griffiths M, Herlocker D and Pennycuick L 1975 The patterns of rainfall in the Serengeti ecosystem, Tanzania. E. Afr. Wildl. J. 13: 347374.

Oguge NO 1995 Diet, seasonal abundance and microhabitats of Praomys (Mastomys) natalensis (Rodentia: Muridae) and other small rodents in a Kenyan sub-humid grassland community. Afr. J. Ecol. 33: 211-223.

Root A (Undated) Islands in a sea of grass. Documentary Film. Tanzania National Parks/Survival Anglia.

Rowe-Rowe DT and Lowry PB 1982 Influence of fire on small mammal populations in the Natal Drakensberg. S. Afr. J. Wildl. Res. 12: 130-139.

Sinclair ARE and Arcese P (eds) 1995 Serengeti II. Dynamics, Management and Conservation of an Ecosystem. University of Chicago Press, Chicago.

Stanley WT, Goodman SM and Hutterer R 1996 Notes on insectivore and elephant shrews of Chome forest, South Pare Mountains, Tanzania (Insectivora; Macroscelidea) Zool. Abhaand. 49: 131-147. 
Stanley WT, Kihaule PM, Howell KM and Hutterer R 1998 Small mammals of Eastern Arc Mountains, Tanzania. J. E. Afr. Nat. Hist. 87: 91-100.

Steele BB, Bayn RL and Val Grant C 1984 Environmental monitoring using populations of birds and small mammals. Analysis of sampling effort. Biol. Cons. 30: 157-172.

Stephenson PJ 1994 Small mammal species richness in a Madagascar rainforest. Afr. J. Ecol. 32: 255-258.

TANAPA 1996 Management Zone Plan/Environmental Impact Assessment for Serengeti National Park. TANAPA, Arusha.
Verhagen R and Verheyen W N 1982 Multiple captures as an indicator of social relations in the wood mouse and the bank vole. Acta Ther. 27: 231-241.

Vesey-Fitzgerald DF 1966 Grazing succession among East African game animals. J. Mammal. 41: 161-172.

Willan K and Bigalke RC 1982 The effects of fire regime on small mammals in South Western Cape Montane Fynbos (Cape Macchia). USDA. For. Serv. Gen. Tech. Rep. 58: 207-212.

Zar JH 1996 Biostatistical Analysis. $3^{\text {rd }}$ edn. Prentice-Hall Inc., New Jersey. 